\title{
ENGLACIAL DELTAIC SEDIMENTS AS EVIDENCE FOR BASAL FREEZING AND MARGINAL SHEARING, LEIRBREEN, SOUTHERN NORWAY
}

\author{
By Charles Harris and Keith Bothamley
}

(Geography Section, Department of Geology, University College, P.O. Box 78, Cardiff CF1 1XL, U.K.)

\begin{abstract}
Aвstract. A frozen englacial band of current-bedded silts, sands, and gravels were observed close to the snout of the temperate glacier Leirbreen. Little-disturbed sedimentary structures indicated a deltaic origin, the lack of disturbance showing that the sediments were frozen prior to their incorporation by the glacier and did not suffer shearing during glacial transport. It was concluded that they accumulated originally in a subglacial pool when the glacier was more extensive than today. Subsequent thinning of the glacier during recession allowed penetration of winter cooling to the base and freezing of subglacial sediments. The resulting layer of frozen sediment was protected from summer thawing by the overlying glacier and might therefore have been subject to further increase in thickness during successive winters. Incorporation of the frozen sediment band into the glacier resulted from compressive flow against the marginal zone of cold-based ice, leading to the development of thrust planes which penetrated through the glacier and into the frozen subglacial material. Shearing along such a thrust plane immediately below the frozen sediment layer, brought it through the glacier to the surface in a relatively undisturbed state.
\end{abstract}

RÉsumÉ. Une assise de sédiment intraglaciaire de type deltaïque, indice du gel au fond et d'un cisaillement près du front au Leirbreen - Norvège du Sud. Un niveau intraglaciaire gelé de limons, sables et graviers déposés par un courant a été observé près du front du glacier tempéré de Leirbreen. Des structure sédimentaires peu perturbées indiquent une origine deltaique, l'absence de perturbation montrant que les sédiments ont été gelés avant leur incorporation par le glacier et n'ont pas souffert du cisaillement pendant le transport glaciaire. On en a conclu qu'ils se sont accumulés à l'origine dans un réseau sous glaciaire alors que le glacier était plus étendu qu'aujourd'hui. Un amincissement ultérieur du glacier au cours d'une période de retrait a permis la pénétration du refroidissement hivernal jusqu'au fond et le gel des sédiments sous glaciaires. Le niveau de sédiments gelés qui en est résulté a été protégé de la fusion estivale par le glacier et peut donc avoir été suje à des accroissements en épaisseur au cours d'hivers successifs.

\section{INTRODUCTION}

Sediments along a $60 \mathrm{~m}$ section of the north-western margins of Leirbreen, in south Norway, were studied in August 1981. Here the glacier flows against a reverse bedrock slope, producing a steep ( $15^{\circ}$ to $\left.16^{\circ}\right)$ compressive lower section with no crevasses (Fig. 1). Shearing close to the ice margin had brought frozen current-bedded silts, sands, and gravels from a subglacial location to the glacier surface, where their gradual release during ablation was associated with only slight internal disturbance. Their incorporation into the glacier is considered to result from basal freezing close to the ice margin.

\section{LOCATION AND RECENT GEOMORPHOLOGICAL HISTORY}

Leirbreen lies on the northern flanks of Smørstabbtinden, $2 \mathrm{~km}$ east of Krossbu in western

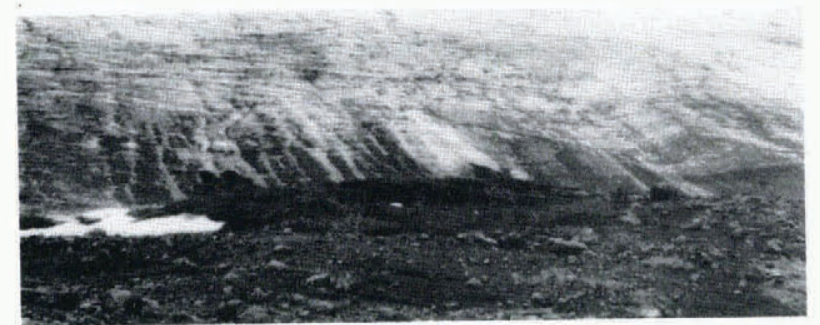

Fig.1. Part of the snout of Leirbreen showing sediments brought to the glacier surface by shearing. Note figures, might centre.
L'incorporation de cette assise de sédiments gelés dans le glacier est due à un écoulement compressif contre la zone marginale de glace basale froide, conduisant au développement de plans d'intrusion qui ont pénétré à traver le glacier et à l'intérieur du matériel sous-glaciaire gelé. Le cisaillement le long d'un tel plan d'intrusion, immédiatement sous le niveau des sédiments, gelés, les à conduit a travers le glacier jusqu'en surface dans un état relativement peu perturbé.

Zusammenfassung Delta-Sedimente aus der Innenmoräne als Beweis für Anfrieren am Untergrund und Scherung am Rande, Leirbreen, Südnorwegen. Nahe der Zunge des temperierten Leirbreen-Gletschers wurde ein gefrorenes Band von fluviatil abgelagertem Schlamm, Sand und Schotter aus der Innenmoräne Beobachtet. Nur wenig gestörte Sedimentstrukturen wiesen auf die Herkunft aus Einem Delta hin, wobei aus dem Fehlen von Störungen geschlossen werden kann, dass die Sedimente vor ihrer Aufnahme durch den Gletscher gefroren waren und während des glazialen Transports keine Scherung erfuhren. Es wurde gefolgert, dass sie ursprünglich in einem subglazialen Teich angesammelt wurden, als der Gletscher eine grösser Ausdehnung hatte als heute. Die Ausdünnung des Gletschers während des Rückzugs erlaubte das Eindringen der Winterkälte bis zum Grund, was zum Gefrieren der subglazialen Sedimente führte. Die hieraus resultierende Schicht gefrorenen Sediments wurde durch den darüber liegenden Gletscher vor dem Auftauen im Sommer geschützt; sie dürfte daher in den folgenden Wintern ihre Dicke noch vergrössert haben. Die Aufnahme des gefrorenen Sedimentbandes in den Gletscher ergab sich durch das kompressive Fliessen gegen die Randzone mit kaltem Eis am Untergrund, das zur Entwicklung von Schubebenen führte, die durch den Gletscher in das gefrorenen subglaziale Material eindrangen. Scherung längs einer solchen Schubebene unmittelbar unter der gefrorenen Sedimentschicht brachte diese in relativ ungestörtem Zustand durch den Gletscher an die Oberfläche.

Jotunheimen (Fig. 2a). Its lower limits lie at an altitude of $1500 \mathrm{~m}$, where the mean annual temperature is approximately $-2.2^{\circ} \mathrm{C}$ with a mean January temperature of around $-10^{\circ} \mathrm{C}$ and mean July temperature $6.5^{\circ} \mathrm{C}$ (based on altitude adjusted data from Fanaraken (2 $062 \mathrm{~m}$ ), Bruun, 1967).

The glacier was visited by de Boer in 1947

(de Boer, 1949), who described shoreline terraces composed of silty sediments occupying a broad shallow gully "recently deserted by the waters of a glacierdammed lake" (de Boer, 1949, p.332). The lake had apparently drained beneath the glacier as a result of thinning and recession. The terraces were still present in 1981, though in a subdued, degraded form, $300 \mathrm{~m}$ to the north of the present study area (Fig. 2a). In 1947 water was flowing from the former ice-dammed lake basin under the glacier, southwards towards an area of concentric crevasses surrounding a depression in the glacier surface, where subsidence into a cavity had apparently taken place. Approximately $140 \mathrm{~m}$ of retreat since 1947 had removed this crevassed area by 1981 and there was no sign of subsidence in the glacier surface. However, the bedrock slope continues to direct glacial melt water southwards beneath the glacier, parallel to the ice margin, as was evidenced by a small stream which emerged from beneath the ice within the present study area (Fig. 2b).

\section{SITE DESCRIPTION}

Shear planes in the steep north-western ice front of Leirbreen showed a somewhat sinuous pattern of outcrop (Fig. 1) and within $30 \mathrm{~m}$ of the glacier edge small amounts of silt and sand were observed melting 

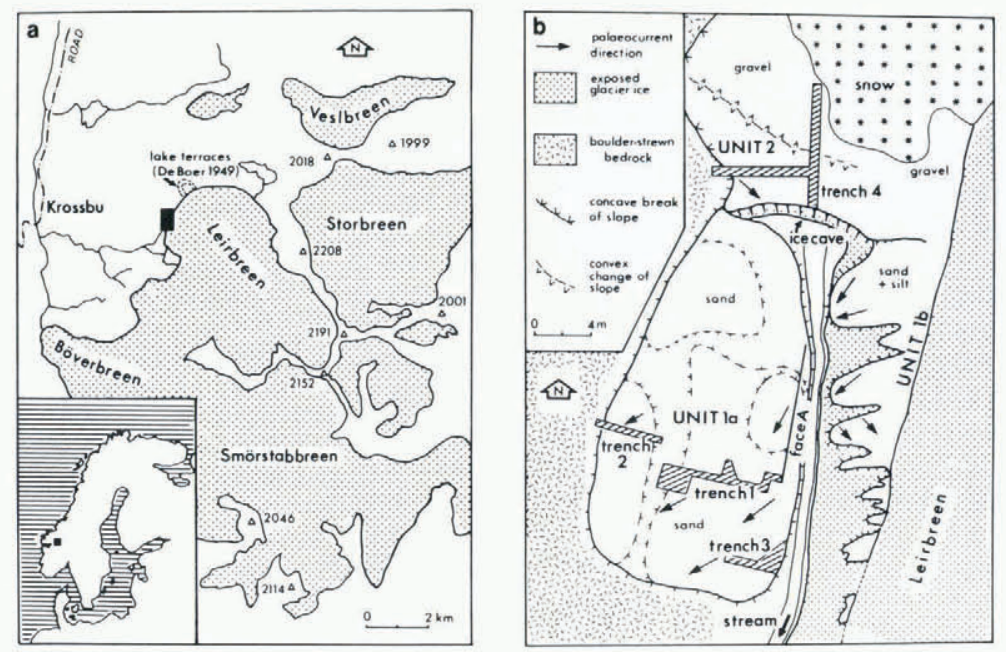

Fig.2. (a) Location map.

(b) Plan of supraglacial and pro-glacial sediment units.

from these shear planes and washing down over the glacier snout in a layer a few centimetres thick. However, associated with the lowermost shear plane, along a $60 \mathrm{~m}$ section of the ice margin, were bedded silts, sands, and gravels forming an irregular layer up to about $1.3 \mathrm{~m}$ thick, extending from its line of outcrop on the glacier down the ice front and beyond the apparent ice limits. A detailed sedimentological analysis will be presented elsewhere (paper on glaciodeltaic sediments at Leirbreen, southern Norway, in preparation by the present authors) and only a brief description will be given here.

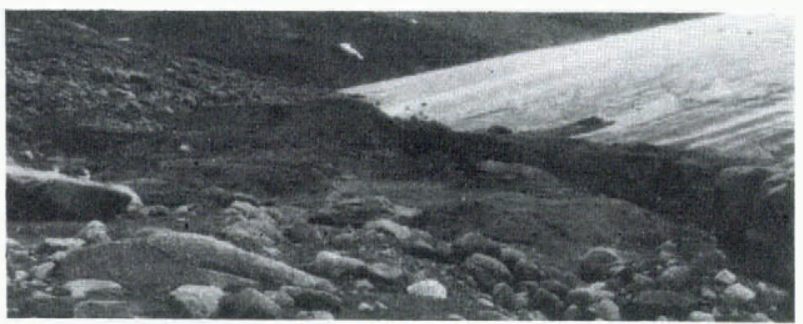

Fig.3. General view of ice margin looking north-east. Note spade, might centre. The sandy unit below the spade (unit 1a) is underlain by glacier ice. The pro-glacial ice-dammed lake terraces occupy a small valley beyond the glacier/bedrock skyline in the middte distance.

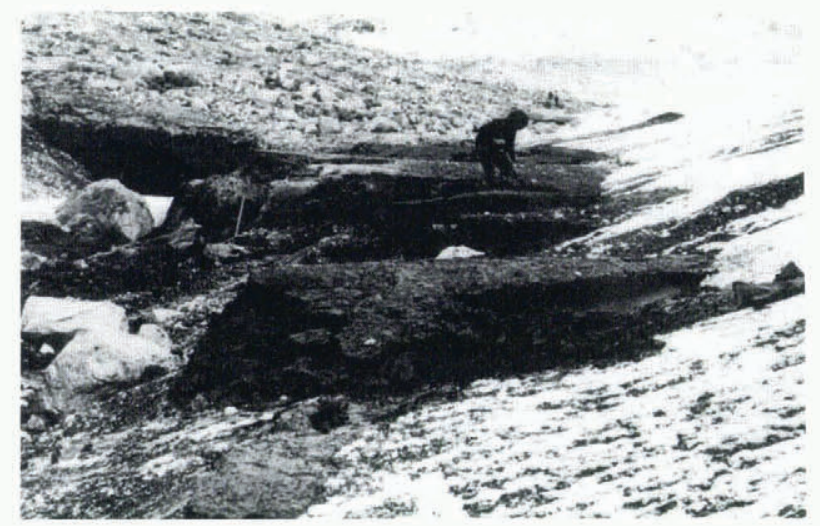

Fig.4. Englacial sediment band melting out on the glacier surface close to the ice margin.
Below the ice cave, from which emerged the meltwater stream, the sediments comprised mainly silts and sands, and were divided into a pro-glacial subunit (unit la) and a supraglacial sub-unit (unit 1b) by the stream channel which followed the ice margin (Figs 2 and 3 ). Above the ice cave, sediment unit 2 comprised gravel and sand and extended from the outcrop of the shear plane to beyond the ice limits, rising to a distinct mound some $1.5 \mathrm{~m}$ high close to the probable limit of glacier ice (Fig. 3).

Along their line of outcrop on the glacier surface these sediments were frozen solid and displayed a sharply defined undulating upper boundary (Fig. 4). Down-slope from their outcrop the sediments were in process of thawing from the surface downwards.

Excavation of unit la (Fig. 2b, trenches 1,2 , and 3) revealed a deltaic sequence (Jopling, [C 1971$]$ ) of foreset and bottomset beds. The topset was, however, replaced by a layer between $30 \mathrm{~cm}$ and $60 \mathrm{~cm}$ thick (Fig. 5) of fluvial granule gravels with channel scour and fill structures interrupted by silt drapes. The underlying foreset layer ranged from $80 \mathrm{~cm}$ in thickness in trench 1 to $30 \mathrm{~cm}$ in trench 3 . The planar cross beds consisted of fine sand, were between $5 \mathrm{~mm}$ and $30 \mathrm{~mm}$ thick, and were cut by small-scale, steeply inclined faults (Fig. 5).

The foreset beds graded through a concave toeset into a silt bottomset with ripple laminations. The bottomset was at most only a few centimetres in

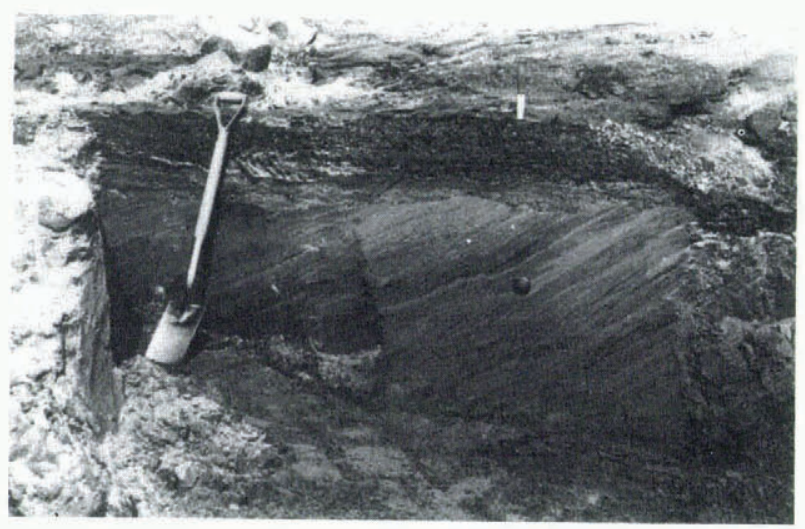

Fig.5. Trench 1 showing foreset beds overlain by gravels containing irregular layers of silt and sand. Note small-scale normal faults in the foreset beds. The spade is resting on frozen sediment and the underlying ice mass is exposed in the right foreground. 


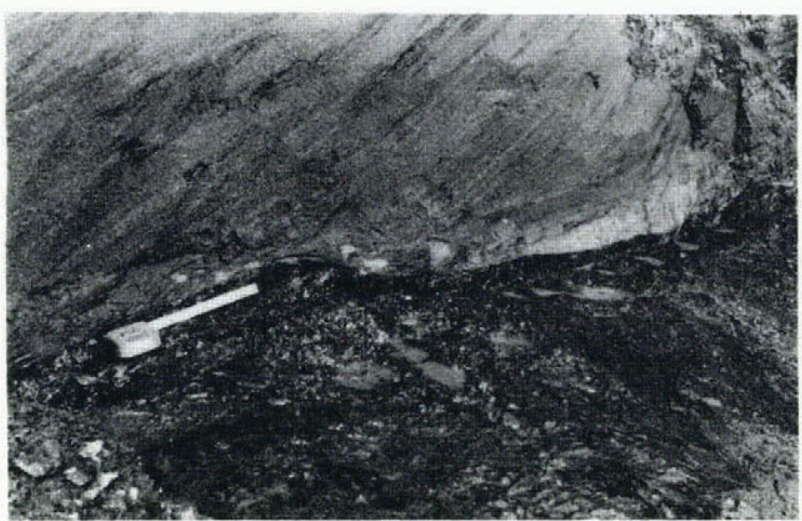

Fig.6. Base of trench 1 showing concave toeset grading into mipple-bedded bottomset silts which are pinched out on the left by the buried ice mass. Note sharp, smooth, undulating boundamy between sediments and buried ice. The scale is approximately $25 \mathrm{~cm}$ in length.

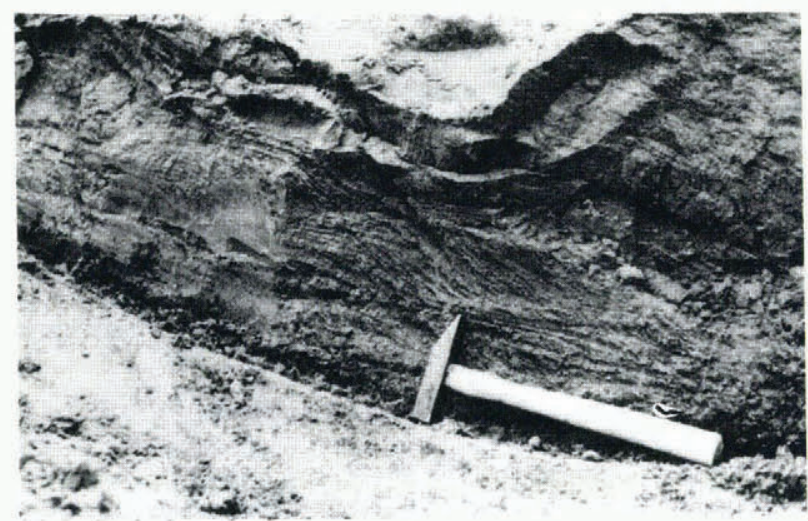

Fig.7. Climbing mipple laminations in englacial sediment band, unit $1 \mathrm{~b}$. The hammer is resting on glacier ice. The mipple laminated silts grade upwards into medium sands.

thickness, being truncated at its base by a buried mass of glacier ice with a sharply defined, smooth, slightly undulating surface (Fig. 6). In places this buried ice pinched out the bottomset completely, abruptly truncating the foresets.

The supraglacial sediments of unit lb ranged in thickness from $20 \mathrm{~cm}$ to $70 \mathrm{~cm}$ and comprised silts and fine sands with well-developed climbing-ripple laminations (Fig. 7). The thickest part of the sequence showed a gradational change from ripple-drift silts at the base to sands above. These silts and overlying sands were texturally indistinguishable from the bottomset and foreset respectively of unit la, and apparently represented a lateral continuation of them. Thawing of these sediments had caused little disturbance of their sedimentary structures. It appeared that in their frozen state they contained no excess ice so that thaw-consolidation was minimal.

Above the ice cave was a kame-like deposit of planar beds of gravels and coarse sand dipping at up to $35^{\circ}$ towards the south-east (unit 2, Fig. 2b). Here the englacial sediment band was $60 \mathrm{~cm}$ thick at its outcrop on the glacier surface and sediment thickness increased down the ice margin to approximately $1.5 \mathrm{~m}$ (Fig. 3).

Pro-glacial topography in this area precludes the accumulation of these sediments in situ, as does the presence of the englacial sediments of unit 1b. Shaw (1982) and Haldorsen and Shaw (1982) have described englacial stratified sediments around the eastern margin of the stagnating glacier Omnsbreen, south Norway. Deposition within englacial passages is described, producing fluvial sediments interstratified with glacier ice. At Leirbreen, however, surface ice gradients, the lack of crevasses, and observations of recent retreat rates, indicate active marginal ice where compressive shearing rather than stagnation is the dominant process. It is unlikely that englacial passages as described at Omnsbreen would remain open in this compressive marginal zone.

It is suggested, therefore, that deposition of the delta originally took place in a subglacial pool ponded against the reverse bedrock slope. The correspondence between palaeocurrent directions in the sediments ( $F$ ig. 2b) and the direction of subglacial drainage from de Boer's ice-dammed lake suggests that subglacial deposition resulted from drainage of the ice-dammed lake, which apparently occurred during the $1940^{\prime}$ s.

MECHANISM OF SEDIMENT INCORPORATION AND DISPLACEMENT BY THE GLACIER

Weertman's mechanism of basal freezing for subpolar glaciers (Weertman, 1961) whereby intact units of frozen subglacial sediment may be incorporated into the base at the transition from warm-based interior to cold-based margin, is well known. Boulton $(1970,1972)$ elaborated on this theory, showing that when unconsolidated subglacial sediment freezes to the glacier, shearing is likely to occur at the boundary between frozen and unfrozen sediment, since this is where shear strength is lowest. Compression in the glacier at the thermal transition leads to the development of thrust planes which extend to the base of the frozen-on sediment, and shearing along the thrust planes brings frozen material to the glacier surface. Menzies (1981) elaborated further on possible modes of subglacial sediment incorporation, and stressed our lack of knowledge regarding temperatures within subglacial debris. The presence of frozen stratified englacial sediments in sub-polar glaciers has been reported by Bishop (1957), Goldthwait (1960), Boulton (1970, [C 1971$])$, and Hooke (1970). Shaw (1971, 1972) described similar incorporation of frozen lacustrine sediments by a Pleistocene ice sheet in Shropshire, England.

In temperate glaciers, ice thrusting close to the margins has been explained in terms of compressive flow resulting from ice thinning (Kupsch, 1962). Gunn (1964) reported thrust planes near the fronts of the Fox and Franz Joseph Glaciers in New Zealand. Flow velocities in these glaciers decreased rapidly near the snout, resulting in transverse foliation dipping up-glacier and thrust planes parallel to the foliation. Morainic debris was incorporated in these thrust planes giving supraglacial ridges referred to by Gunn as "moraine ogives". He did not state whether the debris associated with the thrust planes was frozen, nor did he mention the presence of stratified material. Apparently similar thrust planes with associated debris which formed dirt cones on the surface of Svartisen, north Norway, were described by Stokes (1958).

Okko (1955) mentioned water-lain sediments delivered by shearing to the snout of Hoffelsjökull, Iceland, and Faegri (1934) photographed fluvio-glacial material associated with shear planes at the snout of Nigardsbreen, south Norway. At Midtdalsbreen, Hardangerjøkulen, south Norway, Andersen and Sollid (1971) have described marginal ice-cored moraines derived from till-laden bands emerging from the glacier. Fluvio-glacial sediments were also delivered to the ice front in this way. Andersen and Sollid proposed that debris was frozen onto the base of the glacier close to the snout due to winter cold penetrating through the ice. Freezing of the marginal zone to the bed caused compressive flow and shearing which brought the frozen subglacial material to the surface. Hooke (1981), however, cast doubt on the effectiveness of the shear mechanism in bringing debris from 
the glacier bed to the surface. He cited evidence that debris concentrations in excess of $10 \%$ stiffen ice rather than soften it, making shear along a debris band unlikely. Iken (1981) argued that shear fracture occurs in clear ice above the debris zone rather than within it, although how such shearing would bring debris to the surface was not explained. At Leirbreen the englacial sediment was frozen and its internal sedimentary structures were largely undisturbed. It is probable, therefore, that the sediments were frozen in a subglacial location close to the ice margin by the penetration of winter cold prior to their incorporation by the glacier. A thrust plane then developed through the marginal ice, extending below the frozen-on sediment. Thrusting along this plane brought the frozen debris to the surface. In this example, therefore, it is argued that shearing along a thrust plane took place immediately below the debris band, probably along its lower boundary.

It is generally suggested that the maximum thickness of ice through which winter cooling may penetrate is approximately $15 \mathrm{~m}$ (Boulton, 1972; Derbyshire, 1979; Paterson, 1981). Should basal treezing occur, the resulting frozen subglacial sediments would be protected from summer melting by the presence of overlying ice, the temperature of which cannot rise above freezing. Indeed, near-surface temperature measurements by Paterson (1972) in the ablation zone of the Athabasca Glacier showed ice temperatures remaining below the pressure-melting point throughout the summer. Paterson concluded that where summer ablation is less than the depth of winter cold penetration (c. $15 \mathrm{~m}$ ) near-surface ice may remain permanently below its melting point in the ablation zone.

Ablation at Leirbreen has not, been measured, but at the adjacent glacier, Storbreen, at an altitude of $1400 \mathrm{~m}$ (somewhat lower than the margins of Leirbreen), net ablation has averaged around $2.2 \mathrm{~m}$ during the 1970's (Liest $\varnothing 1,1972-80$ ). At Leirbreen it therefore appears that the surface few metres of ice in the ablation area may not by warmed to the freezing point during the summer.

In the absence of heat conducted from above, thawing of the frozen submarginal sediments can only occur through basal melting by geothermal heat, which would reduce the thickness of the frozen layer only slightly, and by sensible heat carried beneath the glacier by melt water. Clearly, the latter may be locally significant. There are, however, no crevasses at the margins of Leirbreen to allow penetration of melt water and warm air from the ice surface to the glacier bed. In addition, with a negative thermal gradient near the bed of the glacier, heat from laterally penetrating melt water is likely to be conducted upwards to warm and melt the glacier base, as well as downwards to warm and thaw frozen subglacial sediments.

Beneath the marginal zone of Leirbreen, therefore, sediments frozen by winter cooling are likely to remain frozen throughout the following summer, protected from thawing by the overlying ice. It follows that if the ice thickness above a particular location remains less than approximately $15 \mathrm{~m}$ for a number of years, that is the glacier is neither advancing nor retreating rapidly, the thickness of the submarginal frozen sediments would increase annually as the cold wave of successive winters penetrated to the bed. Such incremental freezing over a number of years might well be responsible for producing a submarginal layer of frozen sediments of the extent and thickness observed melting out of the ice surface at Leirbreen in 1981, and described in this paper.

\section{CONCLUSIONS}

A band of deltaic sediments was observed melting out of the glacier surface close to the margins of Leirbreen. Along its outcrop on the glacier surface the sediment band was frozen solid, and ripple laminations in silts and sands were well preserved. On the basis of palaeocurrent directions in the deltaic sequence, it was concluded that deposition occurred subglacially during drainage of an ice dammed lake to the north, during the 1940 's (de Boer, 1949). At that time the glacier was larger than today, the snout extending some $150 \mathrm{~m}$ beyond its position in 1981.

The lack of disturbance in the sediment band exposed in the glacier surface suggested that it was frozen prior to incorporation by the glacier, and that it was not affected by shearing during subsequent glacial transport. Initial subglacial freezing of the sediments, and their freezing onto the sole of the glacier, probably resulted from winter cooling through thin marginal ice. Consideration of the thermal regime suggested that if winter cooling led to freezing of unconsolidated sediments beneath the glacier, they would be protected from subsequent summer thawing by the overlying ice. Further cooling during subsequent winters might then lead to incremental increases in the thickness of the subglacial frozen sediments. Annual winter cooling of glacier ice below its freezing point can be shown to occur to some $15 \mathrm{~m}$ depth, and subglacial frozen sediments are likely, therefore, in a zone within approximately $41 \mathrm{~m}$ of the snout of Leirbreen, where ice thickness is less than $15 \mathrm{~m}$. Such a frontal zone of cold ice, with subglacial frozen sediments, is most likely to occur in higher, more continental glaciers where winter snow accumulation and summer ablation rates are relatively low. It may be an extremely important factor in explaining variations in moraine morphology and composition between different glaciers in Jotunheimen.

At Leirbreen, compressive flow against the bedrock slope, or against cold-based ice frozen to the bed, led to the formation of thrust planes which penetrated through the ice and into the frozen subglacial sediment. Transport through the glacier to the surface resulted from shearing along a thrust plane which lay immediately below the lower boundary of the frozen sediment layer. Internal deformation within the layer itself therefore did not occur. The preservation potential of the resulting ice-cored deltaic sediments is however low, melting of the buried ice will inevitably cause slumping and faulting, and pro-glacial drainage during spring periods of nival thaw is likely to erode the soft sediments rapidly.

\section{ACKNOWLEDGEMENTS}

This research was carried out as part of the University College Cardiff and University of St Andrews Joint Jotunheim Research Expedition, 1981. We thank T. Mellor, J. Hickenbotham and J.A. Matthews for assistance in the field. Financial support to the authors was provided by the British Geomorphological Research Group and University College Cardiff (C.H.), and the United Kingdom Natural Environment Research Council (K.B.), and to the Expedition as a whole by the Royal Geographical Society, the Gilchrist Educational Trust, the Carnegie Trust for the Universities of Scotland, and the Universities of St Andrews and Cardiff.

\section{REFERENCES}

Andersen, J.L., and Sollid, J.L. 1971. Glacial chronology and glacial geomorphology in the marginal zones of the glaciers Midtdalsbreen and Nigardsbreen, south Norway. Norsk Geografisk Tidsskmift, Bd. 25, Ht. 1, p. 1-38.

Bishop, B.C. 1957. Shear moraines in the Thule area, northwest Greenland. U.S. Snow, Ice and Permafrost Research Establishment. Research Report 17. 
Boulton, G.S. 1970. On the origin and transport of englacial debris in Svalbard glaciers. Joumal of Glaciology, Vol. 9, No. 56, p. 213-29.

Boulton, G.S. [C1971.] Till genesis and fabric in Svalbard, Spitsbergen. (In Goldthwait, R.P., ed. TiZl: a symposium. [Columbus], Ohio, Ohio State University Press, p. 41-72.)

Boulton, G.S. 1972. The role of thermal régime in glacial sedimentation. (In Price, R.J., and Sugden, D.E., comp. Polar geomorphology. London, Institute of British Geographers, p. 1-19. (Institute of British Geographers. Special Publication No. 4.))

Bruun, I. 1967. Standard normals 1931-60 of the air temperature in Norway. 0slo, Norsk Meteorologisk Institutt. (Climatological Summaries for Norway.)

Derbyshire, E. 1979. Cryonival and glacial processes. (In Derbyshire, E., and others. Geomorphological processes, [by] E. Derbyshire, K.J. Gregory, J.R. Hails. Folkestone, Wm. Dawson and Sons, Ltd.; Boulder, Colorado, Westview Press, Inc., p. 187-285.)

de Boer, G. 1949. Ice margin features, Leirbreen, Norway. Joumal of Glaciology, Vol. 1, No. 6, p. 332 , 334-36.

Faegri, K. 1933. Uber die Längenvariationen einiger Gletscher des Jostedalsbre und die dadurch bedingten Pflanzensukzessionen. Bergens Museums Arbok, Naturvidenskapelig Rekke, 1933, Nr. 7.

Goldthwait, R.P. 1960. Study of ice cliff in Nunatarssuaq, Greenland. U.S. Snow, Ice and Permafrost Research Establishment. Technical Report 39.

Gunn, B.M. 1964. Flow rates and secondary structures of Fox and Franz Josef Glaciers, New Zealand. Joumal of Glaciology, Vol. 5, No. 38, p. 173-90.

Haldorsen, S., and Shaw, J. 1982. The problem of recognising meltout till. Boreas, Vol. 11, No. 3, p. 261-77.

Hooke, R.L. 1970. Morphology of the ice-sheet margin near Thule, Greenland. Joumal of Glaciology, Vol. 9, No. 57, p. 303-24.

Hooke, R.L. 1981. [In] General discussion. Annals of Glaciology, Vol. 2, p. 187.

Iken, A. 1981. [ $\mathrm{In}]$ General discussion. Annals of Glaciology, Vol. 2, p. 187.
Jopling, A.V. [ ${ }^{{ }}$1971. $]$Some techniques used in the hydraulic interpretation of fluvial and fluvioglacial deposits. (In Yatsu, E., and others, ed. Research methods in geomorphology. Proceedings: 1 st Guelph Symposium on Geomorphology, 1969. Edited by: E. Yatsu [and 4 others]. Don Mills, Ont., Science Research Associates (Canada) Ltd., p. 93-116. (University of Guelph. Geographical Publication No.1.))

Kupsch, W.O. 1962. Ice-thrust ridges in western Canada. Joumal of Geology, Vol. 70, No. 5 . p. 582-94.

Liestфl, 0. 1972-80. Glaciological work. Norsk Polarinstitutt. Arbok, 1970, p. 252-54; 1971 , p. 67-76; 1972, p. 125-36; 1973, p. 181-92; 1974 , p. 183-94; 1977, p. 271-78; 1978, p. 43-52; 1979 , p. 43-51.

Menzies, J. 1981. Temperatures within subglacial debris - a gap in our knowledge. Geology, Vol. 9, No. 6, p. 271-73.

Okko, V. 1955. Glacial drift in Iceland, its origin and morphology. Bulletin de la Commission Géologique de Finlande, No. 170.

Paterson, W.S.B. 1972. Temperature distribution in the upper layers of the ablation area of Athabasca Glacier, Alberta, Canada. Joumal of Glaciology, Vol. 11 , No. 61 , p. 31-41.

Paterson, W.S.B. 1981. The physics of glaciers. Second edition. 0xford, etc., Pergamon Press. (Pergamon International Library.)

Shaw, J. 1971. Mechanism of till deposition related to thermal conditions in a Pleistocene glacier. Joumal of Glaciology, Vol. 10, No. 60, p. 363-73.

Shaw, J. 1972. Sedimentation in the ice-contact environment, with examples from Shropshire, England. Sedimentology, Vol. 18, Nos. 1-2, p. 23-62.

Shaw, J. 1982. Meltout till in the Edmonton area, Alberta, Canada. Canadian Joumal of Earth Sciences, Vol. 19, No. 8, p. 1548-69.

Stokes, J.C. 1958. An esker-like ridge in process of formation, Flatisen, Norway. Joumal of Glaciology, Vol. 3, No. 24, p. 286-89.

Weertman, J. 1961. Mechanism for the formation of inner moraines found near the edge of cold ice caps and ice sheets. Joumal of Glaciology, Vol. 3, No. 30 , p. 965-78. 